\title{
The effectiveness of cross-functional sourcing teams - an embedded case study in a large public organization
}

\section{Cees J. GELDERMAN, Janjaap SEMEIJN \\ Open University of the Netherlands, The Netherlands \\ Esther VERWEIJ \\ Strategic Procurement Consultant at the Province of South Holland, The Netherlands}

\begin{abstract}
:
Aim: To investigate the relationships between team characteristics and their impact on cross-functional sourcing team effectiveness in a public procurement environment.

Design / Research methods: In an embedded single case study, three cross-functional sourcing teams of diverse divisions and departments of the Dutch Province of South Holland are analyzed by means of a comparative analysis.

Conclusions / findings: Teams with greater interpersonal cohesiveness showed more personal and open communication and greater informal frequency of within-team communication. Apparently, task work communication has a positive impact on task cohesion, and interpersonal cohesion has a positive impact on interpersonal communication. A stable team with no changes in roles and membership is likely to show strong task cohesion. Office space for regular meetings and dedicated time for team activities contribute to team effectiveness.
\end{abstract}

Originality / value of the article: Making sourcing decisions is a complex process, particularly in cross-functional sourcing teams with divergent views, objectives, and priorities of the various members of different disciplines. Few studies have examined sourcing teams in the public sector. The study is based on the Input-Mediation-Output-Input model which recognizes mediational factors (processes and emergent states) that transform inputs to outputs. The study contributes to current understanding of the nonlinear linkages between process and emergent states of cross-functional teams in the public sector. The results are useful for public organizations to create more effective cross-functional sourcing teams.

Keywords: cross-functional sourcing teams, team effectiveness, public procurement

JEL: M4

Correspondence address: Kees Gelderman, Open University of The Netherlands, Valkenburgerweg 177, 6419 AT Heerlen, The Netherlands. E-mail: kees.gelderman@ou.nl, janjaap.semeijn@ou.nl, em.verweij@pzh.nl.

Received: 31-08-2017, Revised: 17-09-2017, Accepted: 17-09-2017

http://dx.doi.org/10.29015/cerem.536 


\section{Introduction}

Strategic sourcing involves selecting, developing, integrating and managing suppliers in an effective manner to achieve improvements in the long run in support of an organization's strategic objectives (Driedonks et al. 2014, Talluri, Narasimhan 2004). The focus with strategic sourcing is on long-term partnerships and total cost of ownership rather than short-term price reductions (e.g. Enz, Lambert 2012, Talluri, Narasimhan 2004). Sourcing is highly relevant as the process runs through the entire organization and therefore requires input from many employees with different functions. Increasingly, team structures are being used in a purchasing and supply chain context (Driedonks et al. 2014, Giunipero, Vogt 1997, Johnson et al. 2002, Zheng et al. 2007).The popularity of sourcing teams is in line with the increased awareness of the strategic role of purchasing in many organizations (e.g. Gelderman, Albronda 2017). The use of teams is particularly suitable when a team task directly influences an organization's goals; when organization-wide decisions can only be made with input from personnel of several functional backgrounds; when it is not possible for an individual, function or subunit to manage large and complicated projects effectively; or when the expected value of using a team is higher than the costs (Enz, Lambert 2012, Trent 2003). A sourcing team is often cross-functional or multidisciplinary, which means that it consists of members with different functional experiences and abilities, and who most likely come from different departments or sub-units within the organization (e.g. Kaufmann, Wagner 2017, Kaufmann et al. 2014, Driedonks et al. 2010, Moses, Åhlström 2008, Trent, Monczka 1998).

Cross-functional sourcing teams are established to develop sourcing strategies, identify potential suppliers, analyze supplier capabilities, select suppliers, determine price and conditions of a contract, and evaluate and manage the suppliers' performances for a specific category of products and services. Such teams can flexibly adapt and react to turbulent and dynamic environments and can combine skills, knowledge and abilities and simultaneously make sourcing decisions (Kaufmann, Wagner 2017, Johnson et al. 2002, Trent, Monczka 1994). Sourcing decisions not only affect the organization, but they can also change supply network 
structures and processes (Moses, Åhlström 2008). Consequently, the role of sourcing crosses the boundaries between two distinct domains: internal interactions and external involvement (Driedonks et al. 2014, Luzzini et al. 2015).

Making sourcing decisions is a complex process, particularly in cross-functional sourcing teams with divergent views, objectives, and priorities of the various members of different disciplines (Driedonks et al. 2014, Gevers et al. 2015, Meschnig, Kaufmann 2015). Creating a successful cross-functional sourcing team requires much time and effort. The characteristics of cross-functional sourcing teams are many and varied, and critical to effectiveness (Meschnig, Kaufmann 2015, Trent 1994). Few studies have examined sourcing teams in the public sector (e.g. Glock, Hochrein 2011, Athanasaw 2003). Johnson et al. (2003), for example, analyzed sourcing teams in public institutions and compared their results with studies that focused on the private sector. A better understanding of the characteristics that influence the effectiveness of a cross-functional sourcing team in a public purchasing context could help organizations attain good purchasing performance. This study focuses on cross-functional sourcing teams within a public organization. We empirically investigated the relationships between team characteristics, and their impact on cross-functional sourcing team effectiveness in a public procurement environment. In an embedded single case study, three cross-functional sourcing teams of diverse divisions and departments of the Province of South Holland are analyzed by means of a comparative analysis. The results can be useful for public organizations to create more effective cross-functional sourcing teams.

From a theoretical perspective, the traditional IPO model (Input-Process-Output) has served as a starting point for much team research. Criticism on the IPO model, highlighting cyclical and nonlinear linkages between variables, has led to the development of the Input-Mediation-Output-Input model (Ilgen et al. 2005, Kozlowski, Ilgen 2006). This IMOI model recognizes mediational factors (processes and emergent states) that transform inputs to outputs. Mathieu et al. (2008) pointed out that different processes and emergent states highly correlated with one another. Our study contributes to current understanding of the nonlinear linkages between process and emergent states. Little is known about the way public agencies utilizes sourcing teams for effective procurement initiatives. Public procurement is said to 
be an extremely complicated function, considering its environment that influences and limits the possibilities to accomplish procurement policies/goals. The public procurement system includes many environments, such as the internal environment, the market environment, the legal environment, and the political environment (Thai 2001). Obviously, these issues complicate the functioning and effectiveness of cross functional sourcing teams in the public sector.

\section{Literature Review}

\subsection{Public procurement}

Public procurement professionals are working in an environment more complex than in former times. They must ensure cost efficiency, as it involves a great proportion of public expenditures, must deal with a constantly changing environment (rapidly emerging technologies, increasing product choice), make use of complicated procurement techniques, processes and methods (e-procurement, value for money, life-cycle costing, outsourcing, make or buy decisions). In addition, they are under further pressure as public procurement is used as a policy tool for sustainability, innovation, social return, involve small and medium enterprises (SME) and encourage local development (e.g. Gelderman et al. 2017). Due to its complexity, public procurement has been evolving into a function with a strategic approach which place greater emphasis on supplier management, innovation development, outsourcing of products and services and collaborative long term supplier relationships (Arlbjørn, Freytag 2012, McCue, Gianakis 2001, Thai 2001, Zheng et al. 2007).

Procurement in the public sector has some unique characteristics that differ from purchasing and supply in the private sector. Public procurement professionals are required to observe special rules and regulations, such as the European Union tendering directives, that do not apply to private sector purchasing and supply (Arlbjørn, Freytag 2012, Harland et al. 2013, Reed et al. 2005, Telgen et al. 2007). It is also different because of the frequent existence of a large number of goals, which are difficult to harmonize. Public procurement professionals must achieve value for 
money, but they also need to play a role in broader political goals such as sustainability, innovation, employment, and helping minorities (Erridge 2007, Schapper et al. 2006, Thai 2001). Another difference is the presence of a greater variety of stakeholders such as interest groups, taxpayers and management (Harland et al. 2013, Telgen et al. 2007). The influence of politicians on public procurement is also substantial (Arlbjørn, Freytag 2012, Murray 2009). Furthermore, the requirements of the various stakeholders are likely to be conflicting and impede the possibility of an optimized solution (Harland et al. 2013, Schapper et al. 2006).

Establishing long-term partnerships with suppliers has not been easy for public organizations due to their rules, regulations and culture (Erridge, Greer 2002, Telgen et al. 2007). Public organizations have encouraged a public procurement policy of fair treatment of suppliers, open competition through competitive tendering, and transparency and proportionality of public procurement procedures as the best way to achieve efficient and effective purchasing. Also, there is still a strong emphasis on formal contracts, rigid terms and performance monitoring. Consequently, there is less freedom, flexibility and risk taking in public organizations. Procedures, culture, policies and rules limit the interaction between public procurement employees and suppliers, and restrict the opportunity to close long term relationships which are based on trust, commitment, equality and information-sharing (Erridge, Greer 2002, Erridge, McIlroy 2002).

\subsection{Cross-functional teams in public organizations}

Organizations have entered a new era characterized by rapid, dramatic and turbulent changes, advanced technologies, and globalization (Kaufmann et al. 2014, Leibold et al. 2007, Zheng et al. 2007). The accelerated pace of change has caused public organizations to work more flexibly and responsive to citizens. Public organizations must meet the increasing demands for greater financial accountability, efficiency and effectiveness. These demands require changes in processes, procedures and structures. Increasingly, public organizations are implementing new ways of working (e.g. Coun et al. 2015) that are flexible, efficient and responsive, and new public management principles, such as collaboration, citizen focus, change 
orientation, continuous learning, partnerships and decentralization, are being employed (e.g. Athanasaw 2003, Leibold et al. 2007).

As a result, teams are being used more and more in public organizations in a variety of team-working forms (Parris, Vickers 2005). The study of team structures in organizations in academic literature has been rich and extensive and is rooted in the field of social psychology (Kozlowski, Bell 2003). The use of teams can have many benefits: knowledge, skills, abilities, resources and information can be shared, and productivity, quality, flexibility, innovation, co-ordination, communication and collaboration can be improved (Driedonks et al. 2014, Englyst et al. 2008, Leenders et al. 2005). Teams are particularly relevant for developing complex solutions that involve members of different backgrounds and various stakeholders. However, teams sometimes fail to be effective. The benefits of teamwork are weakened by conflicts or problematic cooperation.

A cross-functional team has many benefits such as improved coordination, integration and communication across functional boundaries (Driedonks et al. 2010, Pinto, Pinto 1990), a general and complete viewpoint of considering a problem brought in by the different disciplines (Luzzini et al. 2015, Parker 2003, Trent, 1996), and higher availability of sources of information and resources (Trent, Monczka 1994). However, members from different functional backgrounds will implicitly have other points of view on many team task issues, which makes integration, coordination and communication difficult. Generally, members of a cross-functional sourcing team are temporarily assigned to the team. Specifically, the organization can have problems with part time members of these teams who are not fully involved and committed (Meschnig, Kaufmann 2015). Often, members report not only to the team leader, but also to their functional managers and have responsibilities not only within the team, but also in their own department. A risk for cross-functional sourcing teams is that their members only represent the interests of their own department, which can create tension and conflict in teams (Moses, Åhlström 2008, Trent, Monczka 1998).

Ilgen et al. (2005) proposed the Input-Mediation-Output-Input (IMOI) model as a superior alternative to the conventional IPO model. They state that many of the meditational factors that transform inputs to outputs are not processes, but are so 
called emergent cognitive or affective states (e.g. team efficacy, team potency, team empowerment, cohesion and trust). The IMOI model shows that the influence of feedback from output to mediators (solid line) is more than the influence of feedback from output to input (dashed line).

The state of a team is particularly influenced by the progression of the team over time. A team, therefore, adapts its processes as a function of the obtained results. The influence of the outputs and mediators on input characteristics, such as team structure, team composition and environmental factors, is less likely. The IMOI model is considered a development model because developmental processes arise over time as teams mature (solid line at the bottom of Figure 1). Moreover, Ilgen et al. (2005) divided team development into three stages: forming (early stages of team development), functioning (teams that have been working together for some time) and finishing (teams that complete the task). Finally, in the IMOI model the interactions between input factors have been depicted as well. The organizational context has, for instance, a substantial influence on team characteristics and members (solid line under input in Figure 1), but the reverse influence is less (dashed line). In this study, the principles of the IMOI framework serve as the starting point for examining the sourcing teams.

\section{Figure 1: Input-Mediator-Output-Input (IMOI) model Team Effectiveness} Framework

\section{Inputs}

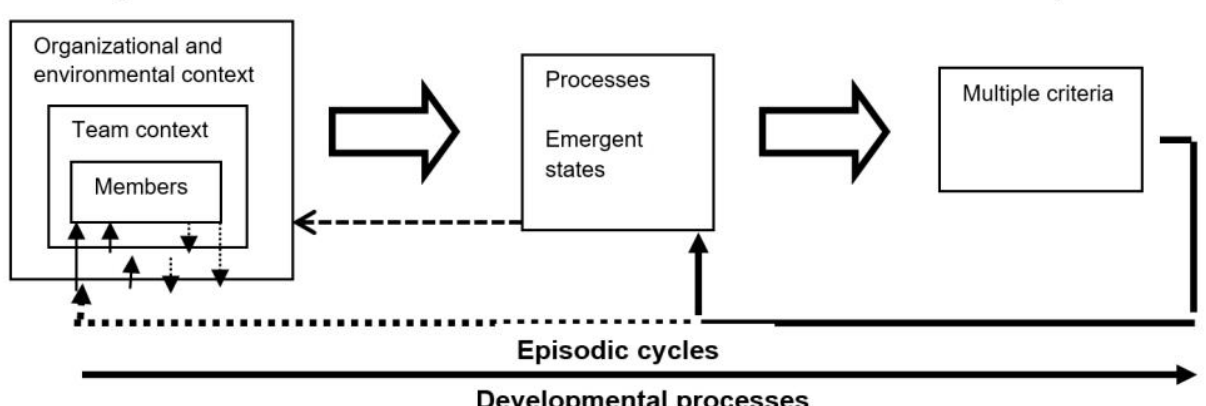

Source: Mathieu et al. (2008) 


\subsection{Research model}

The factors, such as interdependence, membership change and dynamics, communication and team cohesion as input, process or emergent states, were derived from the literature and comprise the research framework together with public procurement and organization characteristics and sourcing team effectiveness. Figure 2 shows the dynamic and complex relationships between sourcing team characteristics, and between the sourcing team characteristics and team effectiveness. The arrows in the model reflect the cyclical nature of crossfunctional sourcing.

The outputs of cross-functional teams is measured as sourcing team effectiveness. This study distinguishes general and specific indicators of sourcing team effectiveness. General sourcing team effectiveness consists of quantity and quality of work produced by the team, number of innovative ideas, efficiency, and ability to communicate, coordinate, and meet targets and performance expectations. Specific sourcing team effectiveness includes improving purchase quality, ameliorating supplier performance, achieving best-in-class supplier selection, and offering support for innovation (Driedonks et al. 2010, Monczka, Trent 1993).

The inputs in the model can be classified into three levels: organizational factors, team-level factors and individual team members characteristics. These inputs can create, facilitate or hinder the functioning of a team. The impact of team variables and member variables are mediated by communication (process) and team cohesion (emergent state). Driedonks et al. (2014) found that communication is a mediator between inputs and sourcing team effectiveness. In addition, team cohesion can be seen as an output of good internal communication as well as a mediator (Holland et al. 2000). Team cohesion was found to mediate the relationship between affective team diversity and team performance (Kaufmann, Wagner 2017). 
Figure 2: Research model of cross-functional sourcing team effectiveness Inputs

Mediators

Outputs

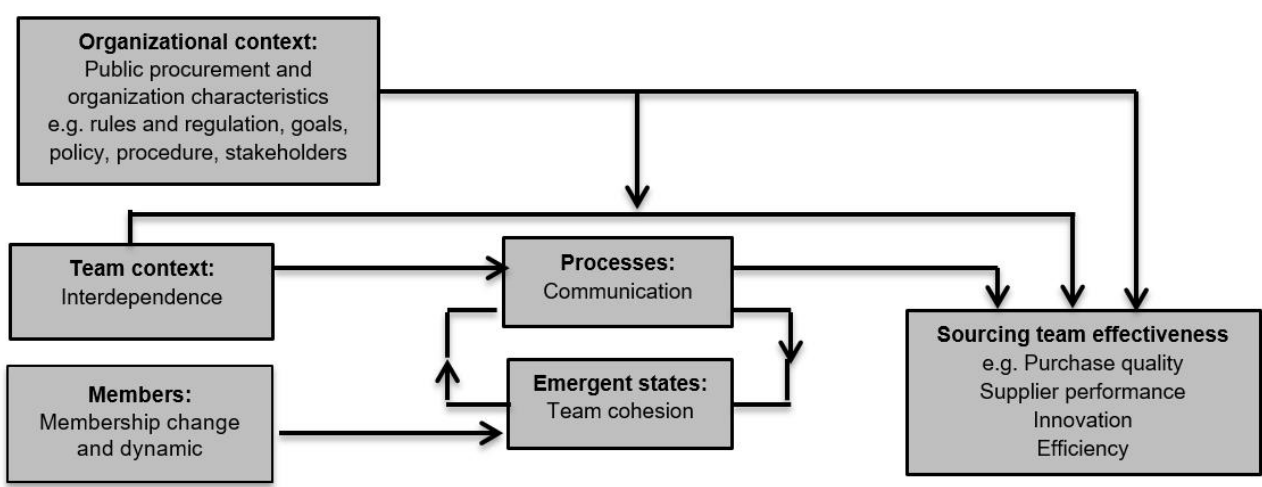

Source: Authors' own elaboration based on Mathieu et al. (2008)

\section{Methodology}

\subsection{Research design}

A case study research design has been chosen for a number of reasons. First, sparse prior research exists relating sourcing team characteristics and sourcing team effectiveness in the public sector. A different context of teams leads to different results, which means that an accurate generalization is not attainable. The lack of attention in the context of public procurement justifies an explorative in-depth case study analysis of the subject. Gaining a rich and new understanding of a specific public procurement context takes precedence over data that can be generalized to other geographical areas or populations. Second, team processes are difficult to statistically observe and measure in organizations due to the dynamic nature of teams (Mathieu et al. 2008, Roe et al. 2012). A case study can provide a unique way of studying complex processes involving many variables (Yin 2014), which quantitative data alone cannot easily reveal. For answering the research question, it is important to offer insights into complex and dynamic team processes. A case study can make it possible to examine in depth values, opinions, behaviors and relationships of people in contemporary and dynamic contexts of a purposive population in different situations. Third, in team research, internal and external organizational context is also very important (Cohen, Bailey 1997, Mathieu et al. 
2008). A real-life phenomenon cannot be separated from its context and the boundaries between the phenomenon and context are difficult to determine (Yin 2014). As such, the interaction between a phenomenon and its context is best understood through an in-depth case study.

The unit of analysis in this study was the entire cross-functional sourcing team and a single embedded case design was adopted. In an embedded case design, within unit analysis, between unit analysis and cross-unit analysis can be applied. The use of cross-functional sourcing teams is not a frequent phenomenon in public organizations (Johnson et al. 2003). The organizational context has been held fixed because a public procurement context is new in the field of sourcing team studies. In order to be able to explore the influences of public procurement and organization characteristics, sourcing teams had to be studied under the same conditions and in the same environment. Three cross-functional sourcing teams of diverse divisions and departments of the Province of South Holland form the subjects of this case study, in which the influence of the characteristics on the effectiveness of the team was analyzed by means of a comparative analysis. After an exploration of the teams in their specific contexts, a more general level than the studied cases could be investigated. Sourcing teams were thus carefully and purposively selected for comparison.

\subsection{Operationalization}

This study focuses on task interdependence, which means the extent to which team members count on each other and act together to complete tasks (Wildman et al. 2011). Moreover, membership change and dynamics refer to new members that replace existing team members and the period of time members have been assigned to the team (Mathieu et al. 2014). Furthermore, the concept communication connotes a two way communication process related to task work or teamwork. Task work communication means reciprocal transfer of information about the task and team solutions and teamwork communication involves the establishment of patterns of interaction (Kozlowski, Bell 2003). Team cohesion can then be classified into task cohesiveness and interpersonal cohesiveness. Task cohesiveness means the extent to which team members are committed or attracted to the team's tasks and goals, while 
interpersonal cohesiveness refers to the extent to which team members like the team and are attracted to each other (Kozlowski, Ilgen 2006). At the same time, sourcing team effectiveness refers to the outputs of the team and can be divided into general sourcing team effectiveness which refers to outputs based on the functioning of the team, and specific sourcing team effectiveness, which address to outputs based on the accomplishment of the task (Driedonks et al. 2010, Monczka, Trent 1993). The operational definitions were used in the interviews. The research framework was translated into a preliminary set of questions to be covered in the interviews. In each interview, respondents were asked to answer questions about the concepts and the relationships among the characteristics, and between the characteristics and effectiveness.

\subsection{Data collection}

A number of criteria were used to select the sourcing teams. First, teams had to consist of members with different functional backgrounds that find, select and manage suppliers for a sourcing category or purchase item. Second, teams had to be different regarding sourcing category with various members from different business units or departments. Third, the team size had to be large enough (more than three members). Fourth, the sourcing process of the teams had to be in the functioning or finishing stage to be able to capture dynamics, experiences and changes in teams.

The head of purchasing of the Province of South Holland was contacted. The Dutch public organization Province of South Holland met all the criteria including large public organization with several organizational divisions (1,700 employees, 3 divisions and 14 departments), use of cross-functional sourcing teams in the organization and large sourcing projects. A list of potential sourcing teams was drafted and key informants (project leaders of sourcing teams) were contacted. As a result, three cross-functional sourcing teams in the same public procurement organization were chosen in order to gain an understanding of the similarities and differences (see Table 1). 
Table 1: Overview of the sourcing teams

\begin{tabular}{|c|c|c|c|}
\hline & $\begin{array}{l}\text { Team } 1 \text { Printers and } \\
\text { copiers }\end{array}$ & $\begin{array}{l}\text { Team } 2 \text { Road } \\
\text { construction }\end{array}$ & Team 3 Cycle paths \\
\hline Organization & Province South Holland & $\begin{array}{l}\text { Province South } \\
\text { Holland }\end{array}$ & Province South Holland \\
\hline Division & Organizational Matters & Space and Mobility & Space and Mobility \\
\hline Department & IT & Projects and programs & Space, housing and land \\
\hline Section & Architecture and support & Projects and programs & Development \\
\hline Type of team & Cross-functional & Cross-functional & Cross-functional \\
\hline Sourcing project & Printers and copiers & $\begin{array}{l}\text { Road construction } \\
\text { parallel structure A12 }\end{array}$ & Cycle paths \\
\hline Team size & Approx. 6 members & Approx. 10 members & Approx. 6 members \\
\hline $\begin{array}{l}\text { Functional areas in } \\
\text { team }\end{array}$ & $\begin{array}{l}\text { Procurement specialist } \\
\text { Procurement lawyer } \\
\text { ICT specialists } \\
\text { Coordinators facility } \\
\text { services } \\
\text { Project leader }\end{array}$ & $\begin{array}{l}\text { Procurement specialist } \\
\text { Project leaders } \\
\text { Engineers } \\
\text { procurement lawyer }\end{array}$ & $\begin{array}{l}\text { Procurement specialist } \\
\text { Program Manager } \\
\text { Engineers } \\
\text { procurement lawyer }\end{array}$ \\
\hline $\begin{array}{l}\text { Stage in sourcing } \\
\text { process }\end{array}$ & Functioning & Functioning & Finishing \\
\hline Date & Since May 2014 & Since November 2010 & Since May 2008 \\
\hline
\end{tabular}

Source: Authors' own elaboration.

Interviews were chosen as the main source of evidence for collecting data. The interviews were generally of the semi-structured type in which different themes were discussed by means of open-ended questions. Semi-structured questions allow for flexibility and provide the chance for more in-depth understandings of some topics. The key informants were also approached for choosing respondents for the interviews based on their own judgment of the most suitable individuals. The interviewees were professionals from various functional areas and participants of cross-functional sourcing teams. Among the interviewees were: procurement experts, consultants, lawyer, ICT specialists, project leaders and other project members. Ten interviews were conducted face-to-face between June and July 2015 and all interviews were audio recorded and transcribed. The interviews lasted approximately between 60 and 90 minutes and were executed by the same interviewer. Prior to each interview, information about the topic and indication of the kind of questions were sent by e-mail for preparation. Data collection involved not only interviews but also document data, thus enabling data triangulation (Yin 
2014). In this way, interview data could be placed in context and an in depth understanding of the relationship between various characteristics and effectiveness could be obtained. Document analysis such as evaluation reports, e-mail correspondence, purchasing and organizational plans and records have been used to confirm information collected through interviews.

\subsection{Data analysis}

Documents were analyzed with the aim of discovering useful information for this study. Relevant documents were sought on the intranet and in the archival system of the Province South Holland. Many suitable documents were available. The public sector has an obligation to keep records in any form (Public Records Act) and to give public access to information (Open Government Act). For this reason, it was easy to find substantial documentation, such as reports, presentations, e-mails, minutes, letters and schedules. On the basis of the core concepts in the research model, the relevant passages were extracted from the documentation. The collected data was classified per criterion.

In the next step, the data of the interviews were analyzed. First, interview transcriptions were made and controlled by the respondents. Following the interview transcriptions, word data was coded and classified into categories according to a data matrix suggested by Miles and Huberman (2014). Key words, sentence fragments and respondents were used to fill the matrix. The data matrix made it possible to determine patterns in the data. Also, cross-case analyses were conducted to identify similarities and differences between sourcing teams. From this comparison, attempts were made to discover tentative relationships between constructs. A case study database was created in order to obtain a chain of evidence. To ensure all interviewees understood the concepts, information about the topic and concepts was also sent a week before interview. To enhance the construct validity in this study, interviews and document analysis were combined to reach triangulation. Several data types such as interview transcripts, documentation and tape recordings were combined. It was important to combine multiple sources and methods of evidence, as teams already existed for some time and at times respondents had difficulty to recall certain issues during interviews. All interviews were recorded and 
soon after the written interview reports were sent to the interviewees for revision and control of misconceptions. Informants received a draft of the case study report for verification.

The case analysis commenced with the identification of meaningful text segments that related to the topic. All coding involves perception and interpretation of what is happening in the data, thus it is a selective and subjective process (Saldaña 2012). During descriptive coding (Miles, Huberman 2014), different data labels were generated from the raw data. The initial long list of data labels was reduced into a smaller number of relevant constructs and categories through pattern coding by clustering the different text segments and reducing overlap and redundancy between the categories. After coding, within case analysis was applied in order to analyze the results in a team. Checklist matrices were used to merge and reduce the data to the team level. A comparison across teams was also explored by means of a cross-case analysis. The within analysis for the teams were compared in a meta-matrix and complemented with relationships existing between the major categories.

\section{Results}

\subsection{Background of the organization}

The case organization is the Province of South Holland. It resides between the Dutch state and the municipalities: literally as "middle government". Every four years the voters in South Holland elect the 55 members of the Provincial States (PS). The Provincial States are the people's representatives and meet every month in the provincial government building in The Hague. They determine the broad outlines and monitor the Executive Council (EC). The EC makes up the daily government of the province. This council is appointed by the PS for a period of four years. The EC carries out the policies and is accountable to the PS. Almost 1,500 employees work on the implementation of provincial tasks. These tasks include spatial planning, managing the regional economy, and creating an attractive environment and functional traffic and transport systems. 
The Province South Holland is governed by a board of three directors and one managing director.The organization introduced a new working mind-set aimed at integral working, customized approaches, modern flexible management, and establishing a learning organization, collaboration and creative thinking. In 2007, a central procurement unit was established with the task of advising and supporting purchasing activities and decisions of the line- and project management. The procurement unit consists of 25 employees (senior buyers, junior buyers, assistant buyers, contract administrators and policy advisors). The procurement manager reports to the head of the department for facility services. The specific departments and sections hold autonomous authority over purchasing decisions and when to include the implementation of contracts and the management of suppliers.

The Province of South Holland started to work with cross-functional teams in 2008 with the task of coordinating the sourcing of chosen commodity groups, mainly services and supplies, in framework agreements. The cross-functional teams for services and supplies are staffed with part time human resources while retaining the prior responsibilities in their respective departments. It is voluntary for the different functional areas to participate in the team's work, but the departments must in principle follow team decisions. A department with a high purchasing budget in a given commodity group or project or specific knowledge of the commodity area in question is responsible for properly performing teams and team based sourcing decisions. The cross-functional teams for construction projects are staffed with permanent resources for a specific period. The teams are authorized to decide on their commodity sourcing strategies, tender process, agreements with suppliers, and the implementation. Most commonly, the teams have five to ten members. It is the responsibility of the project leader to staff the team with sufficient members.

\subsection{Within case analysis}

Team 1 - printers and copiers

During the sourcing project of the printers and copiers team, important developments were taking place in the organization that the team had to take into account, such as relocation, downsizing of the organization, a new way of working (time and place independent work) and greater flexibility and digitization of the 
workplace (such as working with tablets). These developments resulted in the need for less office space and fewer printers and copiers as well as ICT facilities, and an ICT arrangement that supports flexible working. In an open-office design, the use of printers that perform optimally in terms of, for example, factors such as environmental noise and emissions, is more important. One team member noted,

"The most important development was basically: we do not know what we are going to market at all, because there will be fewer printers and more tablets, and we are moving to a new office concept. Yes, it really means that we do not know exactly what we should ask the market either."

In the printers and copiers team, a key element for the successful completion of the sourcing project was that team members were given enough time from their department heads. In addition to their work in the team, the team members had obligations in their own departments. Sometimes, this caused problems with planning of the team, as one team member suggested,

"Schedules are a very important point; people should have enough time and their managers should let them have enough time."

Moreover, the internal stakeholders played a role in the printers and copiers team. Several stakeholders in the organization had to be involved in the sourcing process: the various functional department heads, colleagues in the various departments and other stakeholders in the organization. Frequently communicating with stakeholders and keeping them well informed of the sourcing process ensured that there was no resistance and no disagreements with stakeholders arose to adversely affect the team's work:

"There are also communications outside the team: the communication to and from the stakeholders. This also has an impact on the result. With proper environment management, you keep your team free of disturbances. By designing your environment management well, the environment will not be surprised, allowing the team to continue. It has had no negative impact."

Apparently, internal stakeholders constitute a moderating impact on the relationship between communication and team effectiveness. The effectiveness of taskwork communication was improved by informing and communicating with stakeholders. 
The organization has formulated several goals in the outline agreement. Sustainability and the environment are a key objective of the organization. Contributing to the achievement of the organizational goals is one of the tasks of the teams. Sustainability is included in the selection of suppliers in the printers and copiers team. This has resulted in a sustainable product, as a team member remarked:

"We have sustainable printers that are made from recycled material and we have a certificate with which we contribute to sustainability initiatives in Africa."

Regarding the sourcing processes of a public organization, the Public Procurement law plays a major role. Above a certain purchasing expenditure, a European tender is required. In addition, the procurement procedure has to comply with the procurement rules at all times. The printers and copiers team has followed a new procurement methodology for the European public procurement printers and copiers, which is defined as best value procurement (BVP). Best value procurement is a procurement method that has as few technical requirements as possible, and which requires a detailed description of the scope and budget. BVP allows the distinctive character of the suppliers to be addressed better, the expert to be recognized, a different approach to collaboration with the supplier to be taken and the risks to be reduced. As such, it has provided an extra motivation to have the sourcing project of printers and copiers succeed. This was evident from one team member's comment,

"I think this was our first BVP tender and you want it to succeed, of course. You want it to have a good result and you want to go the occasional extra mile."

It appears that the introduction of BVP as a new purchasing procedure had a positive moderating effect on the relationship between motivation and team effectiveness. The impact of motivation was improved by the adoption of BVP.

In the printers and copiers team, the entry of new-comers to the team or the leaving of a team member had a negative effect on task cohesion. Also, membership dynamics were negatively related to task cohesion. We found a positive relationship between intensive task and knowledge interdependence and internal task work communication. High interdependence caused more task related communication. Although, the task and knowledge interdependence had no direct effect on cross- 
functional sourcing team effectiveness, task and knowledge interdependence have positively influenced the general outcomes of sourcing team effectiveness via communication by creating a better understanding in certain areas of knowledge. It also became clear that task work communication had a positive effect on task cohesion but the opposite effect of task cohesion on task work communication was not found. In contrast, a positive impact of interpersonal cohesion on interpersonal communication was discovered. Organizational and environmental characteristics directly support a number of positive or negative cross-functional sourcing outcomes. The organizational developments like relocation, downsizing of the organization, time and place independent work, and digitization had a direct effect on specific sourcing team effectiveness. It partially determined the quality and quantity of printers and copiers. A printing policy and organizational goals such as sustainability also directly impacted the effectiveness of sourcing teams, as the organization now has sustainable printers and a different quality of printers and copiers. A serious constraint limiting a cross-functional sourcing team's performance is a lack of time available for team assignments. Time availability had a negative effect on team time management, but it had not negatively influenced general sourcing team effectiveness, such as target and performance expectations, because the designated project leader has paid much attention to the coordination and the planning of team activities as well as team member engagement.

\section{Team 2 - road construction}

Generally, the road construction team has experienced considerable influence from the environment outside the organization. The spatial procedures for acquiring and expropriating land in the area where roads have had to be constructed have provided limitations. For approval of the acquisition and expropriation of land, a zoning plan had to be changed and a reference design had to be drawn up at an early stage. Consequently, the planning and land acquisition frameworks were already far advanced at the beginning of the sourcing process, which meant that there was not enough space for contractors to develop innovative solutions. In the words of one team member: 
"The spatial planning and land acquisition has had an impact on what you could ask for. For such an expropriation, the need is also tested, which means you cannot say 'we have actually taken 4 extra meters', so the contractor is more likely to think of something nice".

At the same time, the influence of internal stakeholders on the team performance of the road construction team was rather large. The project was complex and extensive as the entire organization had many interests. Especially departments with much technical knowledge had a significant impact on the team's results, as one team member claimed:

"Stakeholders had a great influence. They were sometimes decisive, because, for example, this process also included a movable bridge. The DBI department is our specialist in this area and it had a fair amount of input, which was decisive for the tendering process."

In addition, external stakeholders have had much influence on the team's performance as well. In the area where the construction project was to take place, there were many divergent interests. The various external stakeholders had to be involved in the project closely, as the road also crossed their territory. Rijkswaterstaat, for example, was an important stakeholder due to the connection of the road to the A12 and A20. ProRail was an important stakeholder as well, as there is a rail connection where the road is being constructed. The municipalities were an important stakeholder due to the land acquisition and land expropriation of their inhabitants.

Furthermore, unlike the printing and copiers team, the road construction team has incorporated sustainability into the sourcing process only to a limited extent. The sustainability criteria of the government to which the Province of South Holland has committed itself and the $\mathrm{CO} 2$ performance ladder are included as requirements in the tender. A team member explained:

"Sustainability did play a role, but it was limited. The policy was only following the principles of the sustainability criteria of PIANOO".

The road construction team has undergone a competitive dialogue within the European tender. A competitive dialogue starts with a question for which no (clear) solution is known. Based on solutions that the contractors bring, a dialogue is 
conducted with the team that can lead to optimization of supply and demand. However, the competitive dialogue procedure has not resulted in open and free discussions with contractors to achieve the best solution possible. On the one hand, the accurately described reference design has given little freedom to contractors and, on the other hand, the strict conditions for conducting a competitive dialogue were a limiting factor. The reason for going through a competitive dialogue was a solution for avoiding traffic problems, the soil conditions and the integration of a movable bridge near an aquaduct. Unfortunately, the team and organization had no experience with conducting a competitive dialogue:

"I think we had too little experience with the competitive dialogue instrument. We found it very difficult to enter into the dialogue with the market. You could not talk freely. For example, you cannot say you like an idea. This made the conversations forced."

In a similar road construction project in the Province of North Holland, a lawsuit with a contractor was pursued just before the start of the sourcing process for the parallel structure A12. Delays due to legal proceedings would have been disastrous for the project of the road construction team. The fear of legal objections influenced the choices made on behalf of the procurement process and one has strongly relied on the advice of external lawyers. Much time and energy was invested in protecting the project against legal proceedings. The law and regulation were able to exert influence in this way.

In the road construction team, the personnel policy has affected the team composition and indirectly the team result. The team was required to take in a reassignment candidate from the mobility center of the organization. This reassignment candidate was given the job of project assistant, but they lacked the necessary knowledge, skills, attitude and behavior. As a result, the team collaboration was jeopardized. As one team member observed:

"It makes the team wonder how to handle a person like that and have one function properly. That has a big impact. You want someone who fits seamlessly into the team and who can work on normal tasks." 
The membership change in the road construction team had a positive effect on task cohesion and interpersonal cohesion. Generally, high membership dynamics have a negative impact on task cohesion. Sequential and reciprocal task and knowledge interdependence appear to have no direct relationship with general sourcing team effectiveness, but there is an indirect effect through communication ( positive or negative). A positive relationship exists between task work communication and task cohesion, but the effect might also be negative in case of inproper communication. In this team, no effect was found of task cohesion on communication. However, we did find a positive impact of interpersonal cohesion on interpersonal communication. Moreover, there is no doubt that the organizational and environmental factors influence effective teamwork. Some factors had a direct influence on specific aspects of sourcing team effectiveness, such as spatial planning and land acquisition, as well as sustainability and stakeholders inside and outside the organization. In addition, team facilities, such as sharing the same office, were positively related to communication, which affects general sourcing team effectiveness. The purchase procedure appeared to be a (negative) moderator of the relationship between communication and specific sourcing team effectiveness. Also law and regulation had a negative moderating effect on the relationship between time management and general sourcing team effectiveness. Finally, staff policy had a direct influence on team composition, which was negative.

\section{Team 3 - cycle paths}

Due to the short period of four years of the Executive Council's term of the Province of South Holland, the cycle paths team became a temporary team, as during the next council's term, one could assume that no funding would be available for cycle paths. Because of the uncertainty of the continuity of the project, it was difficult to find team members for the entire project duration. Partly due to this reason, much use was made of external hiring. Moreover, the cycle paths mentioned team facilities as having a positive effect on communication. One team member stated that working together in close proximity has improved communications. Environmental factors played a strong role in the cycle paths team. These factors influenced the cycle paths' locations as well as the costs: 
"One then further zooms in on the cycle path route. What cables and pipes are there? Are we dealing with culture? Are there any archaeological things? Are there bombs? Is it in nature?"

Moreover, according to the cycle paths team, the 2001 construction fraud affected the regulation. The internal regulations and mandating in the organization has been tightened enormously and a culture of fear is now present. As a result, the process of constructing a cycle path was formerly described in detail in the tender documents. There is thus no room for innovation or ideas from the side of the supplier. This team, however, wanted to approach it differently. But, it was a difficult process to convince those involved in the organization to agree with the new approach.

The cycle paths team has experienced a negative influence from the organization's subsidy unit in particular. In case of collaboration with partners, subsidies had to be taken care of. This process was very rigid and slow. As one team member claimed,

"Previously, we did it in 1 to 3 weeks, but now it took more like 6 months"

Furthermore, many external stakeholders had an influence on the actions and results of the team. Support from water authorities and municipalities is required for the construction of cycle paths. A cycle path often runs through a municipality or on the dikes of the water authorities. Making the external stakeholders ready for a cycle path is not always easy.

Generally, the cycle paths team has not taken into account sustainability and environmental goals. At the start of the sourcing process of cycle paths, the organization had not set sustainability and environmental goals yet. The goal from the outline agreement of the organization that has played a role in the cycle paths team is the realization of $160 \mathrm{~km}$ of cycle paths. At the same time, the cycle paths team experienced problems with the organization's labor capacity. The organization had decided that many cycle paths were to be realized in South Holland in a short amount of time. This proved not to match with the current work capacity, making the team largely dependent on external hiring and outsourcing. The outsourcing of some activities made the team assignment less attractive to some employees. One team member claimed: 
"At some point, there were many problems with regard to the fact that they conducted an administrative unit. We can do it no longer ourselves. Yes, and that image makes it difficult".

In the cycle paths team, conflicting opinions existed about the influence of membership change on task cohesion. It appears to depend on the reason of membership change whether the effect on task cohesion is positive or negative. Membership dynamics had a negative effect on task cohesion.

Conversely, task and knowledge interdependence has positively influenced the general outcomes of sourcing team effectiveness via task work communication. It thus became obvious that task work communication had a positive effect on task cohesion. Also, a positive impact of interpersonal cohesion on interpersonal communication has been revealed. Certain organizational and environmental characteristics relate directly to specific sourcing team effectiveness. In the cycle paths team, environmental factors, such as land acquisition, land expropriation, nature, and cables and pipes, and external stakeholders, had the greatest impact. Furthermore, organizational resource availability, in this case working close to each other, plays an important role in positively affecting the relationship between communication and general sourcing team effectiveness. Organizational developments, including new executive council and budget cuts, have had a direct negative effect on team composition. Similarly, organizational goals related negatively to team composition and membership change. Internal stakeholder appeared to be a negative moderator of the effect between time management and general sourcing team effectiveness, while law and regulation had a negative moderating effect on the relationship between motivation and the output of team satisfaction.

\subsection{Cross case analysis}

This section discusses a comparative analysis of team factors and characteristics most critical for cross-functional sourcing team effectiveness. Table 2 provides insight into organizational and environmental, team and individual input and team processes characteristics. The linkage between cross-functional sourcing team effectiveness and organizational and environmental factors and characteristics is an 
important finding. Organizational developments have a negative impact on specific sourcing team effectiveness. Members in the printers and copiers team explained that the tendering process was complicated by the relocation, downsizing of the organization, time and place of independent work, and digitization of the workplace. This resulted in the use of a new procurement methodology and a different approach to collaboration with the supplier. Organizational developments also had a negative impact on team composition. The cycle paths team, for one, was a temporary team, as a newly elected executive council could decide to cut budgets on cycle paths.

Furthermore, organizational resource availability has had no direct influence on the general team effectiveness, but a positive indirect effect through communication and a negative effect through time management. The amount of time available to commit to the team assignment was mentioned as an organizational resource in team printers and copiers. The members of the printers and copiers team also had responsibilities in their functional department besides their team assignments. As such, team members with a lack of time to pursue a team assignment caused planning and time problems. Also, in the road construction and cycle paths teams, sharing the same office was indicated as a way of improving communication frequency and type (more open and personal). Moreover, external environmental factors had a negative impact on specific cross-functional sourcing team effectiveness. The advanced spatial planning, land acquisition and land expropriation frameworks in team road construction and cycle paths prevented new ideas and innovation.

The internal stakeholders had a moderating effect on the relationship between communication and general sourcing team effectiveness and the relationship between time management and general sourcing team effectiveness. In the printers and copiers team, the internal stakeholders did not negatively influence teamwork, as this team spent much time on communicating with internal stakeholders. Arranging subsidies by the unit subsidy took very long, which jeopardized the project planning in the cycle paths team and negatively influenced their teamwork. Internal stakeholders can have a negative impact on specific sourcing team effectiveness under certain circumstances.The technical department of team road construction was decisive in designing a particular bridge, which made innovation of 
the bridge impossible. External stakeholders have similarly had a negative impact on specific sourcing team effectiveness. Municipalities, water authorities and Rijkswaterstaat prevented innovation due to their specific requirements.

Table 2: Meta-matrix - characteristics influencing sourcing team effectiveness

\begin{tabular}{|c|c|c|c|c|c|}
\hline & Characteristics & $\begin{array}{l}\text { Team printers } \\
\text { and copiers }\end{array}$ & $\begin{array}{l}\text { Team road } \\
\text { construction }\end{array}$ & $\begin{array}{l}\text { Team cycle } \\
\text { paths }\end{array}$ & Impact \\
\hline \multirow{7}{*}{ 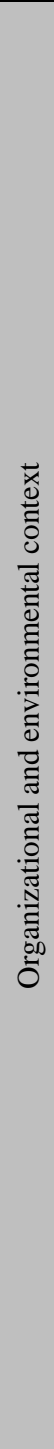 } & $\begin{array}{l}\text { Organizational } \\
\text { developments }\end{array}$ & $\begin{array}{l}\frac{(-) \text { Relocation, }}{\text { new open }} \\
\text { office } \\
\text { concept, tablet } \\
\underline{\text { use (D) }}\end{array}$ & & $\begin{array}{l}\frac{(-) \text { New }}{\text { executice }} \\
\text { council, budget } \\
\text { cuts }(\mathrm{D} \rightarrow \text { team } \\
\text { composition) }\end{array}$ & $\begin{array}{l}\text { Medium } \\
\text { (negative) }\end{array}$ \\
\hline & $\begin{array}{l}\text { Organizational } \\
\text { resource } \\
\text { availability }\end{array}$ & $\begin{array}{l}(-) \\
\text { Availability of } \\
\text { time (SI } \rightarrow \\
\text { time } \\
\text { management) }\end{array}$ & $\begin{array}{l}\frac{(+) \text { Working in }}{\text { the same space }} \\
\underline{(\text { SI } \rightarrow} \\
\underline{\text { communication })}\end{array}$ & $\begin{array}{l}\text { (+) Working } \\
\text { close to each } \\
\text { other }(\text { SI } \rightarrow \\
\text { communication })\end{array}$ & $\begin{array}{l}\text { Mixed } \\
\text { (mostly } \\
\text { positive) }\end{array}$ \\
\hline & $\begin{array}{l}\text { Environmental } \\
\text { factors }\end{array}$ & & $\begin{array}{l}\text { (-) Spatial } \\
\text { planning and } \\
\text { land acquisition } \\
\text { (D) }\end{array}$ & $\begin{array}{l}\frac{(-) \text { Land }}{\text { acquisition, land }} \\
\text { expropriation, } \\
\text { cables and } \\
\text { pipes, nature } \\
\text { (D) }\end{array}$ & $\begin{array}{l}\text { High } \\
\text { (negative) }\end{array}$ \\
\hline & $\begin{array}{l}\text { Internal } \\
\text { stakeholders }\end{array}$ & $\begin{array}{l}\frac{(+) \text { functional }}{\text { department }} \\
\text { managers and } \\
\text { colleagues } \\
\underline{\text { SM } \rightarrow} \\
\underline{\text { communicatio }} \\
\underline{\mathrm{n}}\end{array}$ & $\begin{array}{l}\frac{(-) \text { Functional }}{\text { department DBI }} \\
\underline{(\mathrm{D})}\end{array}$ & $\begin{array}{l}\text { (-) Subsidy unit } \\
(\mathrm{SM} \rightarrow \text { time } \\
\text { management) }\end{array}$ & $\begin{array}{l}\text { Mixed } \\
\text { (mostly } \\
\text { negative) }\end{array}$ \\
\hline & $\begin{array}{l}\text { External } \\
\text { stakeholders }\end{array}$ & & $\begin{array}{l}\frac{(-)}{\text { Municipalities, }} \\
\text { Rijkswaterstaat, } \\
\underline{\text { water }} \\
\underline{\text { authorities (D) }}\end{array}$ & $\begin{array}{l}\frac{(-)}{\text { Municipalities, }} \\
\underline{\text { water }} \\
\underline{\text { authorities (D) }}\end{array}$ & $\begin{array}{l}\text { High } \\
\text { (negative) }\end{array}$ \\
\hline & Organization goals & $\begin{array}{l}\frac{(+)}{\text { Sustainability, }} \\
\frac{\text { environment }}{(\mathrm{D})}\end{array}$ & $\begin{array}{l}\frac{(+)}{\text { Sustainability, }} \\
\text { environment } \\
\underline{\text { (D) }}\end{array}$ & $\begin{array}{l}\frac{(-) 160 \mathrm{~km} \text { cycle }}{\text { paths in short }} \\
\text { time }(\mathrm{D} \rightarrow \text { team } \\
\text { composition, } \\
\text { membership } \\
\text { change) }\end{array}$ & $\begin{array}{l}\text { Mixed } \\
\text { (mostly } \\
\text { positive) }\end{array}$ \\
\hline & $\begin{array}{l}\text { Purchase } \\
\text { procedure }\end{array}$ & $\begin{array}{l}\frac{(+) \text { New }}{\text { purchase }} \\
\text { method BVP } \\
\begin{array}{l}\text { SM } \rightarrow \\
\text { motivation })\end{array}\end{array}$ & $\begin{array}{l}\text { (-) Purchase } \\
\text { method } \\
\text { competitive } \\
\text { dialogue (SM } \\
\rightarrow \rightarrow \\
\text { communication) }\end{array}$ & & $\begin{array}{l}\text { Medium } \\
\text { (mostly } \\
\text { positive) }\end{array}$ \\
\hline
\end{tabular}


Cees J. GELDERMAN, Janjaap SEMEIJN, Esther VERWEIJ

\begin{tabular}{|c|c|c|c|c|c|}
\hline & $\begin{array}{l}\text { Law and } \\
\text { regulation }\end{array}$ & & $\begin{array}{l}\text { (-) Protect } \\
\text { against appeal } \\
\text { procedures (SM } \\
\rightarrow \text { time } \\
\text { management) }\end{array}$ & $\begin{array}{l}\frac{(-) \text { Legal rules }}{(\text { SM } \rightarrow} \\
\underline{\text { motivation })}\end{array}$ & $\begin{array}{l}\text { Medium } \\
\text { (mostly } \\
\text { negative) }\end{array}$ \\
\hline & Policy & $\frac{(+) \text { Printing }}{\text { policy (D) }}$ & $\begin{array}{l}\text { (-) Staff policy } \\
(\mathrm{D} \rightarrow \text { team } \\
\text { composition) }\end{array}$ & & $\begin{array}{r}\text { Medium } \\
\text { (mixed) }\end{array}$ \\
\hline \multirow{3}{*}{ 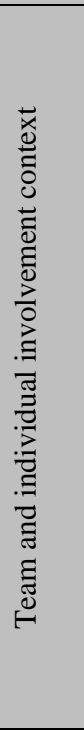 } & Interdependence & $\begin{array}{l}\frac{(+) \text { Intensive }}{\text { task and }} \\
\underline{\text { knowledge }} \\
\underline{\text { interdependen }} \\
\underline{\text { ce }(\text { SI } \rightarrow} \\
\underline{\text { taskwork }} \\
\underline{\text { communicatio }} \\
\underline{\text { n) }}\end{array}$ & $\begin{array}{l}(+) \text { Sequential } \\
\text { and reciprocal } \\
\text { task and } \\
\text { knowledge } \\
\text { interdependence } \\
\begin{array}{l}\text { (SI } \rightarrow \text { taskwork } \\
\text { communication })\end{array} \\
\end{array}$ & $\begin{array}{l}\text { (+) Intensive, } \\
\text { pooled and } \\
\text { reciprocal task } \\
\text { and knowledge } \\
\text { interdependence } \\
(\text { SI } \rightarrow \text { taskwork } \\
\text { communication) }\end{array}$ & $\begin{array}{l}\text { High } \\
\text { (positive) }\end{array}$ \\
\hline & $\begin{array}{l}\text { Membership } \\
\text { change }\end{array}$ & $\begin{array}{l}\frac{(-)}{\text { Retirement, }} \\
\text { holiday }(\mathrm{D} \rightarrow \\
\underline{\text { task cohesion })}\end{array}$ & $\begin{array}{l}\frac{(+) \text { Other skills }}{\text { and knowledge, }} \\
\text { malfunctioning } \\
(\mathrm{D} \rightarrow \text { task and } \\
\text { interpersonal } \\
\text { cohesion })\end{array}$ & $\begin{array}{l}\text { (x) Holiday, } \\
\text { poor chemistry, } \\
\text { joining other } \\
\text { projects }\end{array}$ & $\begin{array}{l}\text { Medium } \\
\text { (mixed) }\end{array}$ \\
\hline & $\begin{array}{l}\text { Membership } \\
\text { dynamics }\end{array}$ & $\begin{array}{l}\frac{(-) \text { Dynamic }}{\text { use and roles }} \\
\text { of team } \\
\text { members, (D } \\
\rightarrow \rightarrow \text { task } \\
\text { cohesion) }\end{array}$ & $\begin{array}{l}\text { (-) Dynamic use } \\
\text { and roles of } \\
\text { team members, } \\
(\mathrm{D} \rightarrow \text { task } \\
\text { cohesion) }\end{array}$ & $\begin{array}{l}\frac{(-) \text { Dynamic use }}{\text { and roles of }} \\
\frac{\text { team members, }}{(\mathrm{D} \rightarrow \text { task }} \\
\underline{\text { cohesion })}\end{array}$ & $\begin{array}{l}\text { High } \\
\text { (negative) }\end{array}$ \\
\hline \multirow{2}{*}{ 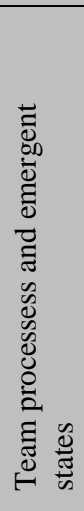 } & Communication & $\begin{array}{l}\text { (+) taskwork } \\
\text { communicatio } \\
\text { n frequecy, (D } \\
\rightarrow \text { task } \\
\text { cohesion) }\end{array}$ & $\begin{array}{l}\text { (+) taskwork } \\
\text { communication } \\
\text { frequency, (D } \\
\rightarrow \text { task } \\
\text { cohesion) }\end{array}$ & $\begin{array}{l}\frac{(+) \text { good }}{\text { taskwork }} \\
\frac{\text { communication, }}{(\mathrm{D} \rightarrow \text { task }} \\
\underline{\text { cohesion })}\end{array}$ & $\begin{array}{l}\text { High } \\
\text { (positive_ }\end{array}$ \\
\hline & Cohesion & $\begin{array}{l}\frac{(+)}{\text { Interpersonal }} \\
\text { cohesion, (D } \\
\rightarrow \\
\underline{\text { communicatio }} \\
\underline{\mathrm{n}} \\
\underline{\text { type/frequenc }} \\
\underline{\mathrm{y})}\end{array}$ & $\begin{array}{l}(+) \\
\text { Interpersonal } \\
\text { cohesion, }(\mathrm{D} \rightarrow \\
\text { communication } \\
\text { type/frequency) }\end{array}$ & $\begin{array}{l}(+) \\
\text { Interpersonal } \\
\text { cohesion, (D } \rightarrow \\
\text { communication } \\
\text { type) }\end{array}$ & $\begin{array}{l}\text { High } \\
\text { (positive) }\end{array}$ \\
\hline
\end{tabular}

$(+)=$ positive effect, $(-)=$ negative effect, underlined text refer to claim made strongly by one person, or by more than one respondent, (x) presence of dissenting or conflicting opinions, (D) $=$ Direct effect, $(\mathrm{S})=$ Side effect, $(\mathrm{SM})=$ Side effect Moderating, $(\mathrm{SI})=$ Side effects Intervening. High impact $=$ claimed by several teams and respondents. Moderate impact = claimed by several respondents in a team. Low impact $=$ claimed by one respondent

Source: Authors' own elaboration. 
The goals of the organization positively influenced specific sourcing team effectiveness. All teams had to take into account sustainability and environment. These goals had a positive impact on the quality of the products. Team cycle paths, for instance, had to reach the goal of $160 \mathrm{~km}$ cycle paths in a short period. This organizational goal directly influenced team composition and membership change. The purchase procedure positively influenced the relationship between motivation and general cross-functional sourcing team effectiveness and negatively influenced the relationship between communication and general sourcing team effectiveness. The new purchase method BVP in the printers and copiers team had a positive influence on motivation and team effectiveness, while "competitive dialogue" in the road construction team had a negative influence on communication and sourcing team effectiveness due to the strict conditions for conducting a competitive dialogue.

Law and regulation had a negative moderating effect on the relationship between time management and general sourcing team effectiveness and a negative moderator effect on the relationship between motivation and team satisfaction outcome. Internal regulations limited the opportunities for new ideas and innovation. Team members lacked motivation due to rules and regulations. Similarly, team road construction communicated to suppliers more than necessary because of the fear of legal objections. Policy had a positive impact on specific sourcing team effectiveness and a direct negative impact on team composition. Team printers and copiers have a different quality of printers and copiers due to the printing policy, while the cycle paths team was obliged to take in a reassignment candidate from the mobility center. No moderating effect of organizational and environmental factors was found between interdependence and sourcing team effectiveness. In all teams, task and knowledge interdependence has positively influenced the general outputs of sourcing team effectiveness via task work communication. More communication was needed due to the task and knowledge interdependence. In all teams, membership dynamics demonstrated less committed team members. Membership dynamics appears to have a negative impact on task cohesion.

We found a relationship between task work communication and task cohesion in all teams. The more communication about tasks and goals, the more task cohesion arose about a shared and clear understanding of a team's purpose and tasks. 
Interpersonal cohesion appeared to be related to communication type in all teams, and also to communication frequency in team printers and copiers and team road construction. Teams with greater interpersonal cohesiveness indicated more personal and open communication and greater informal frequency of within team communication. Task work communication has had a positive impact on task cohesion, and interpersonal cohesion had a positive impact on interpersonal communication, while task cohesion had no impact on team communication.

\section{Conclusions, discussion and recommendations}

\subsection{Conclusions}

We investigated the impact of team characteristics on the effectiveness of crossfunctional sourcing teams. The results indicate that factors in the organizational and environmental context are important characteristics with an impact on sourcing team effectiveness. One important conclusion can be drawn: there is not one effect of the characteristics in the context that is beneficial or detrimental for all teams' effectiveness. The findings indicate that organizational developments, environmental factors, internal and external stakeholders, goals and policy are all important with a direct impact on sourcing team effectiveness (in a negative or positive way). Some contextual factors also directly influenced input factors like team composition or membership change.

Organizational and environmental factors had a negative or positive effect on the interaction between a mediating process and general sourcing team effectiveness. It can be concluded that the environment of the teams is complex and that the teams have a unique nature. Although situated in the same environment, teams had some clear differences with regard to environmental and organizational characteristics because of their varying sourcing team assignments and types of sourcing products. The analysis revealed that membership change can have a negative or positive impact on team effectiveness. Another conclusion is that replacing a malfunctioning team member increases task and interpersonal cohesion. The temporary absence or permanent leave of a team member with good skills and 
knowledge is seen as a shortcoming to a team. Also, a replacement can lower task cohesion. Furthermore, a strong negative relationship between membership dynamics and task cohesion exists in all teams. Thus it can be concluded that a stable team with no changes in roles and membership during the entire sourcing project will benefit from enhanced task cohesion.

Interestingly, though communication and team cohesion were very important, no mutual effect between two constructs were found. Teams with a stronger attractive force and enthusiastic team members communicated more openly and more often, while teams with much task related communication created a strong common interest and commitment to achieve joint goals.

\subsection{Discussion}

Teams have a multilevel nature in which members are part of a team, teams are part of an organization and an organization exists within a wider environment. Contextual characteristics of a team can inhibit or facilitate a good team performance (Kozlowski, Bell 2003, Mathieu et al. 2008, Meschnig, Kaufmann 2015). The empirical findings confirm that contextual and environmental factors are important determinants of team effectiveness. Many previous studies addressed the importance of context on team effectiveness. However, evidence of organizational and environmental factors in the context of a team is often neglected (Kozlowski, Bell 2003, Mathieu et al. 2008). Most research concerning context has been based on organizational factors (factors that are external to team but internal to the organization), including rewards, supervision, training and resources, have been studied the most. Characteristics of the external environment in which the organization is embedded have hardly been studied (Denison et al. 1996, Mathieu et al. 2008).

A positive indirect relationship was found between office space as organizational resource availability and team effectiveness through communication. A negative indirect relationship exists between time availability as organizational resource availability and team effectiveness through time management. Trent and Monczka (1994) found a strong relationship between organizational resource availability and cross-functional sourcing team effectiveness. Similarly, teams with 
access to a work environment achieved high levels of team effectiveness. One of the least correlated resources was time availability. This is in accordance with the findings in this study, as time availability was not indicated as highly significant. Moreover, Holland et al. (2000) state that a larger distance between offices decreases communication between people. Similarly, the results in this study also confirmed the influence of office space on communication.

According to Kozlowski and Ilgen (2006) organizational or environmental characteristics have an influence on the development of team mood and emotions. The empirical results demonstrated that purchase procedure and law and regulation moderate the relation between motivation and general sourcing team effectiveness. Purchase procedure also had a negative moderating effect on the relationship between communication and sourcing team effectiveness. Kaufmann et al. (2014) suggested that too much focus on rational procedures in sourcing team decisionmaking can limit effectiveness. Team processes impact team effectiveness and this relationship can be influenced by contextual circumstances. Several contextual factors had an impact on the relation between task work communication as team process and sourcing team effectiveness. The findings of this study are in line with Ancona (1990). Although several relationships were found between the context and team inputs, team processes and team effectiveness in this study, no relationship was found between context and task interdependence, as suggested by Kozlowski and Bell (2003).

Our framework was based on the IMOI model (Ilgen et al. 2005), which indicates the cyclical and nonlinear linkages between variables. Our study showed mixed results on the relationship between membership change and task cohesion, due to the knowledge, skills and ability of the new or replaced team member. Summers et al. (2012) suggest that the impact of membership change depended on the competencies of leavers and new-comers. Mathieu et al. (2008) posit that empirical research on membership dynamics are rare. Membership dynamics in this study appeared to have a negative relationship with task cohesion. The most significant contribution of this study comes from the investigation of complex and various relationships among the team effectiveness indicators and characteristics about the context in or outside the organization, which gives support to the view of 
the importance of the context of teams. Moreover, in-depth insights have been provided for the nonlinear relationships between variables and the direction of relationships between processes and emergent states, whereas previous studies have not investigated these relationships.

\subsection{Recommendations}

The specific environmental and organizational team context are important. Therefore, it is advisable to start with an analysis of the environment to gain valuable insights into environmental factors, risks, strengths, weaknesses, opportunities and threats to the team. This approach could contribute to a better understanding of the environment and a better preparation to deal with environmental factors and risks. A stakeholder analysis can be useful in order to prevent a negative impact of stakeholders on a team's assignment. Consequently, it is pivotal to make all stakeholders understand the importance of the team and its purpose and priorities. Similarly, teams should spend time communicating with stakeholders to understand their needs and what outcomes they expect from the team (Driedonks et al. 2014). Communication steps with stakeholders should be planned as carefully as any other part of the sourcing project (Kaufmann, Gaeckler 2015). Furthermore, teams should also determine if there are procedural, organizational, environmental or juridical limits that have to be taken into account. For example, are there time or office space limitations that have to be considered? Are there some procedural or juridical constraints that have been deemed undesirable by the team?

Putting team members together during sourcing project on a regular basis strengthens communication and breaks down barriers. A lack of time available to team activities is a serious obstacle to team effectiveness. Team managers and supervisors in the functional department should create additional time for team activities and reduce time spent on other job activities. Another important point is to identify key interdependencies in the team. In a cross-functional sourcing team, team members have heterogeneous skills, knowledge, backgrounds and experiences. A team should know the sequential or reciprocal task steps and should make agreements on how and when to communicate about the tasks before the sourcing project starts. 
Future research could apply a wider variety of indicators and use more objective measures. In this study, the findings were based on available data and events in the past. In one team, respondents had difficulty reflecting on situations because they occurred a while ago. In addition, this study relied on a sample of one public organization. Hence, to increase external validity, future research could take multiple public organizations and multiple sources of data into account. Longitudinal research could further test causality. Similarly, another interesting avenue for future research is the comparison of public and private organizations, in particular with regard to the external environment. In this study, the internal and external context of a team played a crucial role. Future research could focus on potential contextual factors, such as economy or market characteristics (Meschnig, Kaufmann 2015). This study confirms the dynamic nature of participation of team members. Studying team characteristics like membership dynamics and cohesion over time in teams may be a prospect for future research. Finally, it might be interesting to pay attention to the differences in team assignments. 


\section{THE EFFECTIVENESS OF CROSS-FUNCTIONAL SOURCING TEAMS ...}

\section{References}

Ancona D.G. (1990), Outward bound: Strategies for team survival in an organization, "Academy of Management Journal”, vol. 33 no. 2, pp. 334-365.

Arlbjørn J.S., Freytag P.V. (2012), Public procurement vs private purchasing: Is there any foundation for comparing and learning across the sectors?, "International Journal of Public Sector Management", vol. 25 no. 3, pp. 203-220.

Athanasaw Y.A. (2003), Team characteristics and team member knowledge, skills, and ability relationships to the effectiveness of cross-functional teams in the public sector, "International Journal of Public Administration", vol. 26 nos. 10/11, pp. 1165-1203.

Cohen S.G., Bailey, D.E. (1997), What makes teams work: group effectiveness research from the shop floor to the executive suite, "Journal of management", vol. 23 no. 3, pp. 239-290.

Coun M.J.H., Gelderman C.J., Pérez Arendsen J. (2015), Gedeeld leiderschap en proactiviteit in Het Nieuwe Werken (Shared leadership and proactivity in the New Ways of Working), Gedrag en Organisatie, vol. 28 no 4, pp. 356-379.

Denison D.R., Hart S.L., Kahn J. A. (1996), From chimneys to cross-functional teams: Developing and validating a diagnostic model, “Academy of Management Journal”, vol. 39 no. 4, pp. 1005-1023.

Driedonks B.A., Gevers J.M., Van Weele A.J. (2010), Managing sourcing team effectiveness: The need for a team perspective in purchasing organizations, "Journal of Purchasing and Supply Management", vol. 16 no. 2, pp. 109-117.

Driedonks B.A., Gevers J.M., Van Weele A.J. (2014), Success factors for sourcing teams: How to foster sourcing team effectiveness, "European Management Journal", vol. 32 no. 2, pp. 288-304.

Englyst L., Jørgensen F., Johansen J., Mikkelsen O.S. (2008), Commodity team motivation and performance, "Journal of Purchasing and Supply Management", vol. 14 no. 1, pp. 15-27.

Enz M.G., Lambert D.M. (2012), Using cross-functional, cross-firm teams to co-create value: The role of financial measures, “Industrial Marketing Management”, vol. 41 no. 3, pp. 495-507.

Erridge A., Greer J. (2002), Partnerships and public procurement: building social capital through supply relations, "Public Administration", vol. 80 no. 3, pp. 503-522.

Erridge A., McIlroy J. (2002), Public procurement and supply management strategies, "Public Policy and Administration", vol. 17 no. 1, pp. 52-71.

Erridge A. (2007), Public procurement, public value and the Northern Ireland unemployment pilot project, "Public Administration", vol. 85 no. 4, pp. 1023-1043.

Gelderman C.J., Semeijn J., Vluggen R. (2017), Development of sustainability in public sector procurement, "Public Money \& Management", vol. 37 no. 4, pp. 435-442.

Gelderman C.J., Albronda B.J. (2017), Professioneel inkopen (Professional purchasing), 5th edition, Noordhoff Uitgevers, Groningen, The Netherlands. 


\section{Cees J. GELDERMAN, Janjaap SEMEIJN, Esther VERWEIJ}

Gevers J.M., Driedonks B.A., Jelinek M., Van Weele A.J. (2015), Functional diversity appropriateness: Members' and managers' differential perceptions, "Journal of Managerial Psychology', vol. 30 no. 6, pp. 709-725.

Giunipero L.C., Vogt J.F. (1997), Empowering the purchasing function: moving to team decisions, "International Journal of Purchasing and Materials Management", vol. 33 no. 4, pp. 8-15.

Glock C.H., Hochrein, S. (2011), Purchasing Organization and Design: a literature review, "BuRBusiness Research", vol. 4 no. 2, pp. 149-191.

Harland C., Telgen J., Callender G. (2013), International Research Study of Public Procurement, in: The Sage Handbook of Strategic Supply Management, ed. Harland C., Nassimbeni G., Schneller E., Sage Publications Inc., Thousand Oaks, CA, pp. 374-401.

Holland S., Gaston K., Gomes J. (2000), Critical success factors for cross-functional teamwork in new product development, "International Journal of Management Reviews”, vol. 2 no. 3, pp. 231-259.

Ilgen D.R., Hollenbeck J.R., Johnson M., Jundt D. (2005), Teams in organizations: From inputprocess-output models to IMOI models, "Annual Review of Psychology", vol. 56, pp. 517-543.

Johnson P.F., Klassen R.D., Leenders M.R., Fearon H.E. (2002), Determinants of purchasing team usage in the supply chain, "Journal of Operations Management", vol. 20 no. 1, pp. 77-89.

Johnson P.F., Leenders M.R., McCue C. (2003), A comparison of purchasing's organizational roles and responsibilities in the public and private sector, "Journal of Public Procurement", vol. 3 no. 1, pp. $57-74$.

Kaufmann L., Gaeckler J. (2015), On the relationship between purchasing integration and purchasing decision-making speed, "International Journal of Physical Distribution \& Logistics Management", vol. 45 no. 3, pp. 214-236.

Kaufmann L., Meschnig G., Reimann F. (2014), Rational and intuitive decision-making in sourcing teams: Effects on decision outcomes, "Journal of Purchasing and Supply Management", vol. 20 No. 2, pp. 104-112.

Kaufmann L. Wagners C.M. (2017), Affective diversity and emotional intelligence in cross-functional sourcing teams, "Journal of Purchasing \& Supply Management", vol. 23 no. 1, pp. 5-16.

Kozlowski S.W.J, Bell B. S. (2003), Work groups and teams in organizations. In: Handbook of psychology (vol. 12): Industrial and Organizational Psychology , ed. Borman W.C., Ilgen D.R., Klimoski R.J. Wiley, New York, pp. 333-375.

Kozlowski S.W.J., Ilgen D.R. (2006), Enhancing the effectiveness of work groups and teams, "Psychological science in the public interest", vol. 7 no. 3, pp. 77-124.

Leenders M., Johnson P.F., Flynn A., Fearon, H.E. (2005), Purchasing and Supply Management, 13th edition, McGraw-Hill, Chicago.

Leibold M., Probst G.J., Gibbert M. (2007), Strategic management in the knowledge economy: New approaches and business applications, John Wiley, New York. 


\section{THE EFFECTIVENESS OF CROSS-FUNCTIONAL SOURCING TEAMS ...}

Luzzini D., Brandon-Jones E., Brandon-Jones A., Spina G. (2015), From sustainability commitment to performance: The role of intra-and inter-firm collaborative capabilities in the upstream supply chain, "International Journal of Production Economics", vol. 165, pp. 51-63.

Mathieu J., Maynard M.T., Rapp T., Gilson L. (2008), Team effectiveness 1997-2007: A review of recent advancements and a glimpse into the future, "Journal of Management", vol. 34 no. 3, pp. 410476.

McCue C., Gianakis G. (2001), Public purchasing: Who's minding the store?, "Journal of Public Procurement", vol. 1 no. 1, pp. 71-95.

Meschnig G., Kaufmann L. (2015), Consensus on supplier selection objectives in cross-functional sourcing teams. Antecendents and outcomes, "International Journal of Physical Distribution \& Logistics Management”, vol. 45 no. 8, pp. 774-793.

Miles M.B., Huberman A.M. (2014). Qualitative data analysis: An expanded sourcebook, 3rd edition, Sage publications, Thousand Oaks, CA.

Monczka R.M., Trent R.J. (1993), Cross-functional sourcing team effectiveness, Center for Advanced Purchasing Studies, Tempe, AZ.

Moses A., Åhlström P. (2008), Problems in cross-functional sourcing decision processes, "Journal of Purchasing and Supply Management”, vol. 14 no. 2, pp. 87-99.

Murray J.G. (2009), Improving the validity of public procurement research, "International Journal of Public Sector Management", vol. 22 no. 2, pp. 91-103.

Parker G.M. (2003), Cross-functional teams: working with allies, enemies, and other strangers, 2nd edition, Jossey-Bass, San Francisco.

Parris M.A., Vickers M.H. (2005), Working in teams: the influence of rhetoric - from densemaking to dadness, "Administrative Theory \& Praxis", vol. 27 no. 2, pp. 277-300.

Pinto M.B., Pinto J.K. (1990), Project team communication and cross-functional cooperation in new program development, "Journal of Product Innovation Management", vol. 7 no. 3, pp. 200-212.

Reed T.S., Bowman D.E., Knipper M.E. (2005), The challenge of bringing industry best practices to public procurement: Strategic sourcing and commodity councils, in International public procurement conference; challenges in public procurement: an international perspective, PrAcademics Press, Boca Raton, pp. 271-289.

Roe R.A., Gockel C. Meyer B. (2012), Time and change in teams: Where we are and where we are moving, 'European Journal of Work and Organizational Psychology", vol. 21 no. 5, pp. 629-656.

Saldaña J. (2012). The coding manual for qualitative researchers, 2nd edition, Sage Publications, London.

Schapper P.R., Malta J.V., Gilbert D.L. (2006), An analytical framework for the management and reform of public procurement, "Journal of public procurement", vol. 6 no. 1/2, pp. 1-26. 


\section{Cees J. GELDERMAN, Janjaap SEMEIJN, Esther VERWEIJ}

Summers J.K., Humphrey S.E., Ferris G.R. (2012), Team member change, flux in coordination, and performance: Effects of strategic core roles, information transfer, and cognitive ability, "Academy of Management Journal", vol. 55 no. 2, pp. 314-338.

Talluri S., Narasimhan R. (2004), A methodology for strategic sourcing, "European journal of Operational Research", vol. 154 no. 1, pp. 236-250.

Telgen J., Harland C., Knight L. (2007), "Public procurement in perspective" in Public procurement: international cases and commentary, ed. Knight L., Harland C., Telgen J., Thai K.V., Callener, G., McKen K., Routledge, Abingdon, United Kingdom, pp. 16-24.

Thai K.V. (2001), Public procurement re-examined, "Journal of Public Procurement", vol. 1 no. 1, pp. 9-50.

Trent R.J. (2003), Planning to use work teams effectively, "Team Performance Management", vol. 9 nos. 3/4, pp. 50-58.

Trent R.J., Monczka R.M. (1994), Effective cross-functional sourcing teams: Critical success factors, "International Journal of Purchasing and Materials Management", vol. 30 no. 3, pp. 2-11.

Trent R.J., Monczka R.M. (1998), Purchasing and supply management: trends and changes throughout the 1990s, "International Journal of Purchasing and Materials Management", vol. 34 no. 3, pp. 2-11.

Yin R.K. (2014), Case study research: design and methods, 5th edition, Sage publications, Thousand Oaks, CA.

Zheng J., Knight L., Harland C., Humby S., James K. (2007), An analysis of research into the future of purchasing and supply management, "Journal of Purchasing and Supply Management", vol. 13 no. 1, pp. 69-83. 


\section{THE EFFECTIVENESS OF CROSS-FUNCTIONAL SOURCING TEAMS ...}

\section{Efektywność interfunkcjonalnych zespołów sourcingowych - studium przypadku osadzone w wielkiej organizacji publicznej}

\section{Streszczenie}

Cel: Zbadanie zależności pomiędzy cechami zespołów a ich oddziaływaniem na efektywność interfunkcjonalnych zespołów sourcingowych w zielonych zamówieniach publicznych.

Metodyka badań: W pojedynczym studium przypadku przeanalizowano za pomocą analizy porównawczej trzy interfunkcjonalne zespoły sourcingowe z różnych wydziałów i departamentów niderlandzkiej Prowincji Południowej Holandii.

Wnioski: W zespołach cechujących się większą spójnością interpersonalną miała miejsce bardziej osobista i otwarta komunikacja oraz lepsza nieformalna częstotliwość wewnątrzzespolowej komunikacji. Najwidoczniej, komunikacja związana z pracą zadaniową ma pozytywny wpływ na spójność zadania, zaś spójność interpersonalna ma pozytywny wpływ na komunikację interpersonalną. Stabilny zespół, w którym podział ról i członkostwo nie podlegają zmianom, zwykle wykazuje się silną spójnością zadaniową. Do zespołowej efektywności przyczyniają się przestrzeń biurowa służąca do regularnych spotkań oraz czas wyznaczony na aktywność zespołu.

Wartość artykułu: Podejmowanie decyzji o pozyskiwaniu kandydatów stanowi złożony proces, zwłaszcza $\mathrm{w}$ przypadku interfunkcjonalnych zespołów sourcingowych złożonych $\mathrm{z}$ różnych przedstawicieli odmiennych dyscyplin, $\mathrm{z}$ rozbieżnymi poglądami, celami oraz priorytetami. Kilka badań poświęcono zespołom sourcingowym w sektorze publicznym. Niniejsze badanie zostało oparte na modelu Input-Mediation-Output-Input (IMOI), pozwalającym rozpoznać czynniki mediacyjne (procesy i nagłe stany), transformujące nakłady w wyniki (wejście na wyjście). Badanie przyczyniło się do obecnego rozumienia nieliniowych związków pomiędzy procesami i nagłymi stanami interfunkcjonalnych zespołów $\mathrm{w}$ sektorze publicznym. Wyniki są użyteczne dla organizacji publicznych $\mathrm{w}$ odniesieniu do budowania bardziej efektywnych interfunkcjonalnych zespołów sourcingowych.

Słowa kluczowe: interfunkcjonalne zespoły sourcingowe, efektywność zespołu, zamówienia publiczne

JEL: M4 